\title{
PERBEDAAN INFORMASI ANATOMI PADA SEKUEN T1WI TSE POST GADOLINIUM DENGAN FATSATURASI MAUPUN TANPA FAT SATURASI PADA PEMERIKSAAN MRI LUMBAL
}

\author{
Marichatul Jannah $^{1)}$, Sugiyanto ${ }^{2)}$, Irwan Katili ${ }^{3)}$, Edy Susanto ${ }^{4)}$ \\ 1), 2), 3), 4) Jurusan Teknik Radiodiagnostik dan Radioterapi Poltekkes Kemenkes Semarang \\ Jl. Tirto Agung Pedalangan Banyumanik Semarang
}

\begin{abstract}
Backgroud: Fat Saturation is useful in MR Imaging to supress high signal from fatty tissues. When Fat Saturation is used in combination with gadolinium, enhancing lessions become more conspicuous. T1 post-contrast examination usually does not require fat saturation, in Dr. Hasan Sadikin Hospital Bandung combined with fat saturation. Another interesting things are the tumor, metastasis and inflammation will be isointense on $\mathrm{T} 1$ enhance contrast but still added Fat Saturation. The objectives of this research is to find out anatomy information differences between TIWI TSE Post Gadolinium with and without Fat Saturation and acknowledge which better anatomy information between two pulse sequences.

Methods: The research uses quantitative method with experimental approach and questionnaire. The research takes place at Radiology Unit RSUP Dr. Hasan Sadikin Bandung on May-June 2013 with 20 patients with a variety of cases using gadolinium and 5 respondents. Data analysis uses univariate method, wilcoxon test, and friedman test

Results: The research result shows that are differences anatomy information between TIWI TSE Post Gadolinium with and without Fat Saturation by P value 0,000 (sig.<0,05). The anatomy information has good present on the first treatment T1WI TSE Post Gadolinium with Fat Saturation pulse by mean rank 2,99.
\end{abstract}

Keywords : MRI, T1WI TSE Post Gadolinium, Fat Saturation, Anatomy Information

\section{Pendahuluan}

Lumbal sebagian besar terdiri dari lemak yang merupakan komponen molecular dengan atom hydrogen pada cairan sehingga sulit dibedakan antara lemak dengan jaringan lunak disekitarnya. Untuk mengatasi hal tersebut, maka dikembangkan suatu teknik yang disebut Fat Saturation (Fat Sat).

Pada pemeriksaan dengan kasus metastasis, khususnya yang mengenai vertebrae dilakukan dengan Short TI Inversion Recovery (STIR) atau pembobotan T2 fat suppresi maupun menggunakan media kontras dengan pembobotan T1 (Brant Zawadzki, 2002). Media kontras yang dipergunakan dalam MRI adalah gadolinium (Gd) yang merupakan substansi paramagnetik yang mempunyai momen magnet yang cukup besar yang disenyawakan dengan diethylene triaminepentaacetic acid (DTPA) agar tidak berbahaya dan mudah diekskresikan dari dalam tubuh (Westbrook, 2002). Menurut Siemens (2013) Fat Sat bekerja dengan baik setelah pemasukan media kontras gadolinium (Gd).

Berdasarkan pengamatan penulis di Instalasi Radiologi RSUP Dr. Hasan Sadikin Bandung menggunakan sekuen T1WI TSE (Turbo Spin Echo) dengan mempertimbangkan waktu pemeriksaan yang lebih cepat dibandingkan dengan menggunakan sekuen Spin Echo. Hal ini dikarenakan penggunaan "echo train length" dimana terjadi banyak pengulangan pulsa $180^{\circ}$ dalam satu TR (time repetition). Selain itu, apa yang dilakukan di rumah sakit tersebut sedikit berbeda dengan apa yang disampaikan oleh Zawadzki (2002) khususnya dalam pemilihan pulsa sekuen. Sebagai contoh, pemeriksaan T1 post kontras yang biasanya tidak diperlukan fat saturation, di rumah sakit tersebut justru dikombinasikan dengan fat saturation. Hal lain yang juga menarik adalah tumor, metastase maupun peradangan akan isointense pada T1 enhance kontras tetapi masih ditambahkan sekuen Fat Saturation.

Hasil penelitian yang dilakukan oleh Robert, dkk (1992) menunjukkan hasil bahwa contrast enhancement fat saturation teknik mampu menampakkan enhance lesi yang dikelilingi oleh lemak dan mampu mendeteksi kelainan pada struktur dengan kadar lemak yang tinggi. Hasil ini lebih baik jika dibandingkan dengan T1 Post Kontras tanpa penambahan Fat Sat.

Berdasarkan paparan latar belakang tersebut, maka penulis tertarik untuk mengkaji lebih lanjut dalam penelitian yang berjudul "Perbedaan Informasi Anatomi pada Sekuen T1WI TSE Post 
Gadolinium dengan Fat Saturasi maupun tanpa Fat Saturasi pada Pemeriksaan MRI Lumbal".

\section{Metode}

Penelitian ini termasuk jenis penelitian kuantitatif dengan pendekatan eksperimental. Penelitian ini dilakukan di Instalasi Radiologi RSUP Dr. Hasan Sadikin Bandung pada bulan Mei-Juni 2013 dengan jumlah sampel sebesar 20 pasien dengan berbagai kasus yang menggunakan gadolinium. Teknik pengumpulan data dengan metode kuesioner yang dibagikan kepada 5 orang responden. Analisis data menggunakan analisis univariat, uji wilcoxon, dan uji friedman.

\section{Hasil dan Pembahasan}

\section{Analisis Statistik dengan metode Wilcoxon Perlakuan 1}

Perlakuan 1 merupakan perlakuan pada MRI Lumbal post Gd dengan scanning Fat Sat terlebih dahulu kemudian tanpa Fat Sat

Tabel 1. Hasil Analisis Uji Wilcoxon

\begin{tabular}{|c|c|l|}
\hline Variabel & P Value & \multicolumn{1}{|c|}{ Kesimpulan } \\
\hline Bone Marrow & 0,003 & $\mathrm{H}_{\mathrm{o}}$ ditolak \\
\hline Disk Intervertebra & 0,041 & $\mathrm{H}_{\mathrm{o}}$ ditolak \\
\hline Lemak & 0,000 & $\mathrm{H}_{\mathrm{o}}$ ditolak \\
\hline CSF & 0,020 & $\mathrm{H}_{\mathrm{o}}$ ditolak \\
\hline Spinal Cord & 0,023 & $\mathrm{H}_{\mathrm{o}}$ ditolak \\
\hline Kejelasan patologi & 0,000 & $\mathrm{H}_{\mathrm{o}}$ ditolak \\
\hline
\end{tabular}

\section{Perlakuan 2}

Perlakuan 2 merupakan perlakuan pada MRI Lumbal post Gd dengan scanning tanpa Fat Sat terlebih dahulu kemudian dengan Fat Sat.

Tabel 2. Hasil Analisis Uji Wilcoxon

\begin{tabular}{|c|c|l|}
\hline Variabel & P Value & \multicolumn{1}{|c|}{ Kesimpulan } \\
\hline Bone Marrow & 0,022 & $\mathrm{H}_{\mathrm{o}}$ ditolak \\
\hline $\begin{array}{c}\text { Disk } \\
\text { Intervertebra }\end{array}$ & 0,005 & $\mathrm{H}_{\mathrm{o}}$ ditolak \\
\hline Lemak & 0,000 & $\mathrm{H}_{\mathrm{o}}$ ditolak \\
\hline CSF & 0,011 & $\mathrm{H}_{\mathrm{o}}$ ditolak \\
\hline Spinal Cord & 0,083 & $\mathrm{H}_{\mathrm{o}}$ diterima \\
\hline $\begin{array}{c}\text { Kejelasan } \\
\text { patologi }\end{array}$ & 0,003 & $\mathrm{H}_{\mathrm{o}}$ ditolak \\
\hline
\end{tabular}

Hasil Penilaian Gambaran Informasi Anatomi Secara Keseluruhan

Table 3. Hasil penilaianresponden secara keseluruhan terhadap informasi anatomi sekuen T1WI TSE Post Gd Fat Sat maupun tanpa Fat Sat

\begin{tabular}{|c|c|c|}
\hline $\begin{array}{r}\text { Informasi } \\
\text { Anatomi }\end{array}$ & Mean Rank & $\begin{array}{c}\text { Tingkat } \\
\text { Kemaknaan }\end{array}$ \\
\cline { 1 - 2 } FSP1 & 2,99 & \multirow{2}{*}{ P value $=$} \\
0,000 \\
NFSP1 & 2,41 & Sig $<0,05$ \\
\cline { 1 - 2 } NFSP2 & 2,66 & \\
\hline FSP2 & 1,94 & \\
\hline
\end{tabular}

Keterangan :

FSP1 : Fat Sat Perlakuan 1 NFSP1:

Non Fat Sat Perlakuan 1 NFSP2:

Non Fat Sat Perlakuan 2 FSP2 : Fat

Sat Perlakuan 2

1. Perbedaan Informasi Anatomi antara Sekuen T1WI TSE Post Gd Fat Sat maupun tanpa Fat Sat pada pemeriksaan MRI Lumbal.

Gambaran bone marrow dari kedua perlakuan dengan analisa Uji Wilcoxon menunjukkan hasil bahwa ada perbedaan yang signifikan antara gambaran bone marrow pada sekuen T1WI TSE Post Gd Fat Sat maupun tanpa Fat pada perlakuan I dengan nilai $\mathrm{P}$ value sebesar 0,003 (Sig.<0,05). Gambaran bone marrow pada perlakuan II menunjukkan hasil bahwa ada perbedaan yang signifikan dengan nilai $\mathrm{P}$ value sebesar 0,022 (Sig.<0,05). Hal ini sesuai dengan teori Van Goethem (2007) bahwa enhancement gadolinium akan meningkatkan sinyal pada bone marrow sebesar $26,4 \% \pm 8,6 \%$ pada usia $27-35$ tahun dan $17,5 \% \pm 7,9 \%$ pada usia 35 tahun keatas. Sehingga penambahan aplikasi Fat Sat setelah enhancement dapat memperjelas kelainan bone marrow, memperlihatkan kelainan intraspinal, serta kelainan organ yang dikelilingi lemak.

Gambaran diskus intervertebralis dari kedua perlakuan dengan analisa Uji Wilcoxon menunjukkan hasil bahwa ada perbedaan yang signifikan antara gambaran diskus intervertebralis pada sekuen T1WI TSE Post Gd Fat Sat maupun tanpa Fat pada perlakuan I dengan nilai $\mathrm{P}$ value sebesar 0,041 (Sig.<0,05). Gambaran diskus intervertebralis pada perlakuan II menunjukkan hasil bahwa ada perbedaan yang signifikan dengan nilai P value sebesar 0,005 (Sig. <0,05). Gambaran diskus intervertebralis menampilkan detail gambar yang lebih jelas pada T1WI TSE Post Gd tanpa Fat Sat. Walaupun pada teknik Fat Sat gambaran diskus intervertebralis tampak hiperintense, namun detail dengan objek disekitarnya tidak terlalu jelas sehingga sulit dideteksi jika terdapat kelainan.

Gambaran lemak dari kedua perlakuan dengan analisa Uji Wilcoxon menunjukkan hasil bahwa ada perbedaan yang signifikan antara gambaran lemak pada sekuen T1WI TSE Post Gd Fat Sat maupun tanpa Fat pada perlakuan I dengan nilai P value sebesar 0,000 (Sig.<0,05). Gambaran lemak pada perlakuan II menunjukkan hasil bahwa ada perbedaan yang signifikan dengan nilai $\mathrm{P}$ value sebesar 0,000 (Sig.<0,05). Hal ini sesuai dengan hasil penelitian yang dilakukan oleh Robert, dkk (1992) bahwa contrast enhancement fat saturation teknik mampu menampakkan enhance lesi yang dikelilingi oleh lemak dan mampu mendeteksi kelainan pada struktur dengan kadar lemak yang tinggi. Namun, Fat Sat membutuhkan magnetic field 
homogenities yang tinggi untuk mencegah ketidakrataan teknik fat supresi yang ada. Fat Sat tidak merata disebabkan oleh FOV yang besar dan magnetic field inhomogenities. Solusinya yaitu dengan mengaplikasikan magnetic field shimming dan menggunakan FOV yang kecil.

Gambaran CSF dari kedua perlakuan dengan analisa Uji Wilcoxon menunjukkan hasil bahwa ada perbedaan yang signifikan antara gambaran CSF pada sekuen T1WI TSE Post Gd Fat Sat maupun tanpa Fat pada perlakuan I dengan nilai $\mathrm{P}$ value sebesar 0,020 (Sig.<0,05). Gambaran CSF pada perlakuan II menunjukkan hasil bahwa ada perbedaan yang signifikan dengan nilai $\mathrm{P}$ value sebesar 0,011 (Sig.<0,05).

Gambaran Spinal Cord dengan analisa Uji Wilcoxon pada perlakuan I menunjukkan hasil bahwa ada perbedaan yang signifikan antara gambaran CSF pada sekuen T1WI TSE Post Gd Fat Sat maupun tanpa Fat pada perlakuan I dengan nilai $\mathrm{P}$ value sebesar 0,023 (Sig.<0,05). Gambaran CSF pada perlakuan II menunjukkan hasil bahwa tidak ada perbedaan yang signifikan dengan nilai $\mathrm{P}$ value sebesar 0,083 (Sig.<0,05). Walaupun gambaran spinal cord tidak menampakkan perbedaan yang terlalu mencolok pada kedua sekuen, tetapi pada sekuen T1WI TSE Post Gd masih menampilkan gambaran yang lebih baik dan berbatas tegas.

Gambaran kejelasan patologi dari kedua perlakuan dengan analisa Uji Wilcoxon menunjukkan hasil bahwa ada perbedaan yang signifikan antara gambaran kejelasan patologipada sekuen T1WI TSE Post Gd Fat Sat maupun tanpa Fat pada perlakuan I dengan nilai $\mathrm{P}$ value sebesar 0,000 (Sig. <0,05). Gambaran kejelasan patologi pada perlakuan II menunjukkan hasil bahwa ada perbedaan yang signifikan dengan nilai $\mathrm{P}$ value sebesar 0,003 (Sig.<0,05). Hal ini sesuai dengan hasil penelitian yang dilakukan oleh Robert, dkk (1992) bahwa tumor, metastase maupun peradangan akan isointense pada T1 enhance kontras. Sehingga ditambahkan sekuen Fat Sat bertujuan untuk meningkatkan intensitas dan homogenitas contrast enhancement serta menekan intensitas sinyal pada epidural fat.

\section{Hasil Penilaian Informasi Anatomi Secara Keseluruhan}

Berdasarkan Uji Friedman, didapatkan nilai mean rank dari kedua jenis perlakuan. Uji Friedman menunjukkan adanya perbedaan informasi anatomi yang signifikan antara sekuen T1WI TSE Post Gd Fat Sat maupun tanpa Fat Sat dengan nilai $\mathrm{P}$ value $=0,000$ (sig. <0,05). Namun, sekuen T1WI TSE Post Gd Fat Sat pada perlakuan I mempunyai nilai mean rank paling tinggi yaitu 2,99.

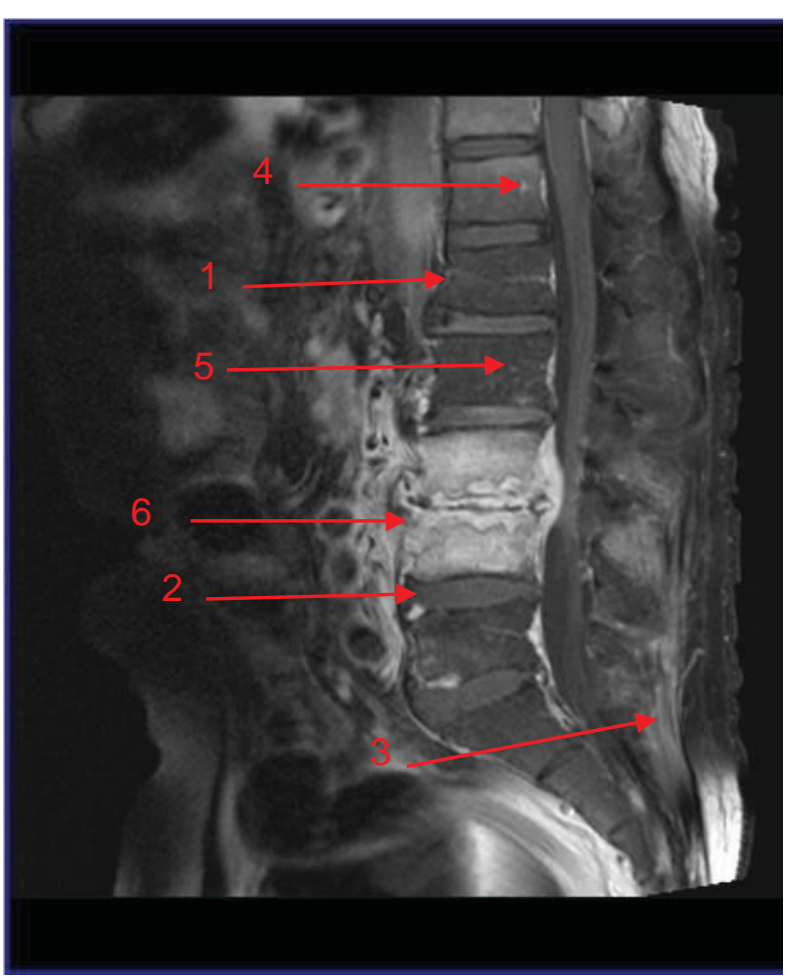

Gambar 1. Fat Sat pada perlakuan 1 dengan kasus Spondilitis TB dengan paravertebrae abses L3-4

\section{Keterangan :}

1. Bone Marrow

2. Diskus Intervertebralis

3. Lemak

4. Spinal Cord

5. CSF

6. Kejelasan Patologi

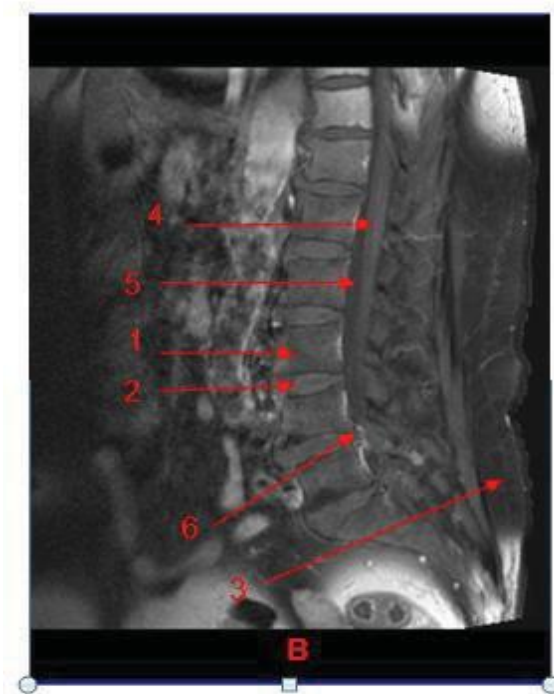

Gambar 2. Fat Sat pada perlakuan 2 dengan kasus Spondiloarthrosis L3-5 dan HNP L4-5 (B)

Keterangan :

1. Bone Marrow

2. Diskus Intervertebralis

3. Lema 
1. Spinal Cord

2. CSF

3. Kejelasan Patologi

Berdasarkan nilai mean ranktersebut, maka dapat ditarik kesimpulan bahwa teknik Fat Sat pada perlakuan I lebih baik dibandingkan pada perlakuan II. Hal tersebut dikarenakan Fat Sat merupakan teknik yang menggunakan chemical shift-selective $R F$ saturation pulse yang diaplikasikan pada lipid peakyang diikutispoiler gradient pulse. Sehingga, Fat Sat mampu membedakan lesi dari jaringan lemak disekitarnya dengan hanya menekan proton pada lemak saja. Namun, Fat Sat dapat menimbulkan pergerakan pada pasien karena membutuhkan banyak waktu untuk mengaplikasikan fat selective saturation RF pulse dan dephasing gradient serta dapat meningkatkan SAR (Specific Absorption Rate) pada pasien (Robert, dkk 1992;Blink, 2004). Kekurangan pada Fat Sat adalah adanya supresi lemak yang tidak merata pada bagian posterior lumbal, dapat dilihat pada gambar 4.1 Hal ini mungkin terjadi disebabkan oleh inhomogenitas medan magnet. Hasil penelitian ini juga didukung oleh penelitian Robert, dkk (1992) bahwa T1WI enhancement contrast tanpa aplikasi Fat Sat memperlihatkan homogenitas pada epidural fibrosis sebesar 19\%. Namun, pada enhance T1WI Fat Sat mampu memperlihatkan homogenitas yang lebih tinggi yaitu sebesar $52 \%$. Interval waktu diantara dua akuisisi contrast enhancement sebesar 9 menit pada range waktu 5-15 menit.

Pada perlakuan II yaitu setelah enhancement kontras tidak langsung diaplikasi dengan Fat Sat, justru diperoleh hasil bahwa sekuen T1WI TSE Post Gd dengan Fat Sat mempunyai nilai mean rank yang lebih rendah daripada sekuen T1WI TSE Post Gd tanpa Fat Sat. Hal ini disebabkan oleh interval waktu akuisisi diantara kedua sekuen sebesar 10 menit, sehingga ada jeda waktu sebelum pemberian Fat Sat dan diperkirakan kontras sudah melewati organ yang diperiksa. Hal ini didukung oleh Michael (1991) yang menyatakan bahwa pada spinal imaging, epidural venous plexus akan menampakkan enhancement setidaknya 10-20 menit pada bagian neural foramen pada cervikal dan bagian posterior vertebral body pada lumbal. Enhancement juga tampak pada daerah ventral dan dorsal nerve root ganglion, khususnya pada bagian lumbal. Namun, normal cord, nerve root, dan diskus intervertebralis tidak akan mengalami enhancement. Gadolinium secara bertahap diekskresikan melalui ginjal dengan waktu paruh biologis sekitar 90 menit, sehingga pada kebanyakan pasien tidak terdeteksi dalam jaringan sekitar 6 jam meskipun berada dalam urin dan kandung kemih selama sehari (McRobbie, 2006).

\section{Simpulan}

Ada perbedaan informasi anatomi yang signifikan antara sekuen T1WI TSE Post Gadolinium dengan Fat Saturasi maupun tanpa Fat Saturasipada pemeriksaan MRI Lumbal dengan nilai $\mathrm{P}$ value $=0,000$ pada nilai signifikansi $<0,05$. Informasi anatomi yang lebih baik pada sekuen T1WI TSE Post Gadolinium dengan Fat Saturasi pada Perlakuan I.

Sebaiknya dilakukan penambahan sekuen Fat Saturasi setelah enhancement media kontras pada pemeriksaan MRI Lumbal. Perlu dilakukan penelitian lebih lanjut untuk mengetahui penggunaan teknik Fat Saturasi pada kasus seperti marrow edema, marrow hyperplasia, dan marrow hemmorrage.

Sebaiknya dilakukan shimming manual sebelum menjalankan sekuen untuk mengurangi inhomogenitas medan magnet.

\section{Daftar Pustaka}

Bitar, Richard, et al. 2006. MR Pulse Sequences: What Every Radiologist Wants to Know but is Afraid to ask. RSNA Volume 26, Number 2.

Blink, Evert J. 2004. MRI : Physics. support@mriphysics.com

Brown, M.A dan Richard C. Semelka. 2003. MRI Basic Principle and Applications, Third Edition, John Wiley and Sons Inc, New Jersey.

Bushong, Steward C. 1995. MRI Physical and Biological Principles, CV. Mosby CO:Missoury.

Cameron, 2009. Techniques of Fat Suppression. Di akses tanggal 1 Mei 2013.

Emanuelle, dkk. 1999. Fat Supression in MR Imaging: Techniques and Pitfalls. Radiographics RSNA Volume 19, Number 2.

Fast, Avital and Goldsher. 2007. Navigation The Adult Spine. CV Mosby Co:Missouri.

Hornak, JP. 2011. The Basic of MRI. www.cis.rit.edu. Di akses tanggal 1 Mei 2013.

IMAIOS. 2010. Spin Echo, TR, TE, www.imaios.com/en/e-Courses/e-MRI. Di akses tanggal 1 Mei 2013.

Mc Robbie, Donal et al. 2006. MRI from picture to Proton, Second Edition. New York.

Michael, 1991. Advances in Contrast Enhanced MR Imaging. AJR Online diakses tanggal 10 Agustus 2013.

Moeller dan Reif. 2003. MRI Parameters and Positioning. New York: Thieme.

Nesseth, R. 2000. Procedures and Dokumentation for CT and MRI, McGraw-Hill, Medical Publising Division, USA. 
No name. 2003. Pulsa Sequences. http://www.revisemri.com/questions/. Di akses tanggal 1 Mei 2013.

Robert, dkk. 1992. Diseases of The Lumbar Spine : Findings on Fat Suppression MR Imaging. AJR Online diakses tanggal 5 Juli 2013.

Scarabino, dkk. 1996. Fast Spin Echo Imaging vertebral metastases:Comparisson of Fat Supression Tehniques. Dipartimento di Diagnostica per Immagini-IRCCS Casa Sollievo della Sofferenza-San Giovanni Rotondo (FG), Ancona.

Siemens. 2013. The Skinny On Fat Sat. Siemens Medical Solutions, Inc : USA.

Westbrook dan Kaut. 1998. MRI in Practice, Second Edition. London:Blackweel Science.

Westbrook, Catherine. 1999. Handbook of MRI Technique, Second Edition.

Westbrook, Chaterine. 2002. MRI at a Glance. Blackwell Science Ltd : United Kingdom.

Woodward, Peggy and William W. Orrison. 1997. MRI Optimization ; A Hands-on Approach Mc. Graw Hill : New York, USA. 